\title{
Authors and Soldiers: Reconstructing History in Postwar Japan
}

Kyle Grossman

Pomona College, Class of 2012

In 1940s and 1950s Japan, dominant histories of the Pacific War-the Asian-Pacific front of World War II-emerged that simplified the disparate experiences of those involved and influenced the memory of the conflict's storytellers. In particular, there have been two officialized histories of the war and postwar periods - the former constructed by the Japanese wartime state, and the latter framed by Japan's Allied occupiers. The Japanese government imposed the unifying spirit of kokutai (national spirit or character) onto its citizens, portraying them as completely loyal to the Emperor and fully devoted to the total war effort. During occupation, the Allies represented the war as a misguided effort by the Japanese political and military leadership who victimized the people, forcing them into ravaging the Asian continent. America was Japan's liberator, giving the people a democratic government promoting egalitarianism and freedom of expression. But were there no efforts to problematize these officialized histories that obviously elided the war's complexities?

An examination of postwar Japanese literature reveals that writers not only engaged with the dominant histories characterizing the Pacific War, but they also often subverted, undermined, and overturned such narratives. The medium of literature allows writers to reach out to mass publics, and thus gives authors the ability to shape society's historical conceptionsperhaps by perpetuating dominant views, rejecting generally accepted norms, or creating entirely new historical frameworks. This paper focuses on three authors who wrote during the Allied Occupation-Haruo Umezaki, Shohei Ooka, and Hiroshi Noma-in order to contextualize the writings of Akira Yoshimura and Hikaru Okuizumi, who produced works in the decades following American withdrawal from Japan in 1952. Furthermore, it examines their works dealing specifically with soldier experiences-Umezaki's 1946 "Sakurajima," Ooka's 1948 Taken Captive and 1951 Fires on the Plain, Noma's 1952 Zone of Emptiness, Yoshimura's 1967 Typhoon of Steel, and Okuizumi's 1993 The Stones Cry Out. ${ }^{1}$ These were the men who saw the effects of Japan's total war mobilization on the ground. These were the men who most forcefully were

\footnotetext{
${ }^{1}$ Haruo Umezaki, "Sakurajima" in The Catch and Other War Stories, translated by D.E. Mills (Tokyo: Kodansha International Ltd., 1981); Shohei Ooka, Taken Captive: A Japanese POW's Story, translated by Wayne P. Lammers, (New York: John Wiley \& Sons, 1996); Shohei Ooka, Fires on the Plain, translated by Ivan Morris, (Boston: Tuttle, 2001); Hiroshi Noma, Zone of Emptiness, translated by Bernard Frechtman, (Cleveland: The World Publishing Company, 1956); Akira Yoshimura, Typhoon of Steel: An Okinawan Schoolboy's Quest for Martyrdom in the Battle of Okinawa, translated by Mark Ealey, (Portland, ME: Merwin Asia, 2009); Hikaru Okuizumi, The Stones Cry Out, translated by James Westerhoven, (New York: Harcourt Brace \& Company, 1998).
} 
expected to adhere to a sacrificial and duty-bound mindset, for their success dictated that of Japan. And these were the men whose fighting was silenced, whose millions of deaths were a part of that "aberration" in Japan's otherwise successful history. ${ }^{2}$ By framing their novels through the soldier experience (and often basing them on their own), postwar writers remembered the war through those affected by it. Moreover, by framing their novels through the soldier experience (and often basing them on their own), postwar writers recounted an experience that was, at least in some sense, common to all-with millions conscripted, every Japanese either fought or knew someone fighting.

T. Fujitani, Lisa Yoneyama, and Geoffrey White proposed two particularly helpful theories for analyzing how people remember events and experiences: "memory work" and "critical remembering." Memory work involves the creation of narratives; it "continually figures and refigures the past as a method for present purposes." ${ }^{3}$ It is particularly "acute" when what is remembered concerns the experiences of war-massive destruction, violence, and oppression. ${ }^{4}$ The outcomes of war change social and political landscapes, and therefore the remembering of such conflicts can become "dangerous," involving "urgent and intense political stakes"-a distorted memory could harmfully alter a postwar world. ${ }^{5}$ Looking at these five authors' own refigurings of the war sheds light on whether they agreed or disagreed with the dominant narratives and why their remembrances were significant to their times. Related to "memory work" is "critical remembering." Those who critically remember seek to "denaturalize and dismember" dominant memories by recuperating those memories lost, suppressed, or distorted by the "effects of power"-those memories overshadowed by the officialized narrative. ${ }^{6}$ Furthermore, historian Lisa Yoneyama asked a particularly pertinent question in her book Hiroshima Traces: "How can memories, once recuperated, remain self-critically unsettling?"7 This question implicitly addressed the danger of creating new dominant histories. Once an individual "critically remembers" or uncovers one of those lost or suppressed memories, how does this memory remain unsettling to the dominant narrative and continue to challenge historical assumptions? Determining whether or not postwar Japanese writers created a new dominant narrative out of the soldier experience is important. If a new officialized history has arisen, then perhaps these authors' "critical remembrances" have lost their vitality, lost their ability to give soldiers "historical agency," falling into a Yoneyamian memory trap of sorts. ${ }^{8}$

Before delving into postwar writers' works and remembrances, it is crucial to understand two significant outlooks on the Pacific War: the Japanese state's propagandistic portrayal of the

\footnotetext{
${ }^{2}$ T. Fujitani, Geoffrey M. White, and Lisa Yoneyama, Introduction to Perilous Memories: The Asia-Pacific War(s), (Durham: Duke University Press, 2001), 7.

${ }^{3}$ Ibid, 1.

${ }^{4}$ Ibid, 2.

${ }^{5}$ Ibid, 2.

${ }^{6}$ Ibid, 5 .

${ }^{7}$ Lisa Yoneyama, Hiroshima Traces: Time, Space, and the Dialectics of Memory, (Berkeley: University of California Press, 1999), 5.

${ }^{8}$ Ibid, 33.
} 
war, and the dominant history of the war that arose in the postwar period. All of the authors discussed below responded to these two narratives and subverted, promoted, or rewrote them to some degree. We would not be able to comprehend the full effects of their "memory work" without situating them within the wartime and postwar narrative frameworks. ${ }^{9}$ The first of these perspectives - the militaristic Japanese government's wartime ideology - centered on a total war rhetoric stressing an unwavering Japanese support of the state's endeavors. It was an ideology of subjection, demanding complete and blind loyalty to the country and the emperor.

The state was present in every aspect of military and civilian life. The government infiltrated Japanese social networks through neighborhood associations, community councils, the tokko (special higher police) and the kenpeitai (military police), media and literature censors and other restrictive laws, and the Ministry of Education's widespread. This propaganda served as an ideological backdrop contextualizing the state's other restrictive policies. Three of the most widely distributed and representative propaganda pieces were the Ministry of Education's Kokutai no hongi and The Way of Subjects, and the War Ministry's Field Service Code. ${ }^{10}$ These three texts aimed to create a dominant strain of historical and nationalist thinking while silencing and neglecting any oppositional viewpoints-they thus promoted what Lisa Yoneyama calls an "official knowledge" or "official History" of Japanese culture, society, and economy. ${ }^{11}$ In a sense, the Japanese state engaged in "memory work" through such propagandistic pieces, refiguring the nation's history to tell a specific story about the Japanese people. This reworked historical narrative stressed the unity of the "hundred million" strong and fealty to the deity incarnate emperor-it elevated the Japanese above all others, advocated a mission to liberate and guide Asian peoples to prosperity, and praised the nation's ability to eschew destructive Western individualism while successfully adapting industrialism to Japanese society. ${ }^{12}$ Japan was meant to construct "a new world order based on moral principles" by adhering to a "structure of national unanimity in politics, economy, culture, education, and all other realms of national life." ${ }^{13}$ With Kokutai and The Way of Subjects, the aptly named Thought Bureau sought to implant in the Japanese consciousness a viewpoint of unity, superiority, and loyalty that would mobilize the nation for total war. The state apparatuses described further below forced the populace to contribute to the war and unrelentingly imposed this propagandistic spirit of Kokutai and The Way of Subjects onto the Japanese citizenry.

The government forcefully aimed to control the minds and bodies of servicemen with its wartime ideology. Every soldier read the Field Service Code which stressed "complete obedience

\footnotetext{
${ }^{9}$ When I mention authors' "memory work" and "critical remembering," I am, of course, not saying that they had these theories in mind while they were writing. Rather, I am saying that they reworked narratives and unearthed memories in a way that allows their books to be considered examples of "memory work" and "critical remembering." ${ }^{10}$ Kokutai No Hongi: Cardinal Principles of the National Entity of Japan, translated by John Owenn Gauntlett, edited by Robert King Hall (Cambridge: Harvard University Press, 1949); The Way of Subjects, Appendix A in Otto D. Tolischus, Tokyo Record (New York: Reynal \& Hitchcock, 1943); Field Service Code, Tokyo Gazette, Vol. IV, no. 9, 1941.

${ }^{11}$ Ibid, 27.

${ }^{12}$ Kokutai No Hongi, 65, 80, 82, 91, 105, 137, 152, 157.

${ }^{13}$ The Way of the Subjects, 408, 417.
} 
to His Majesty," promoted the ability to fight as "one in spirit and body and in single-hearted loyalty," and commanded the soldier to "sacrifice himself for the whole... without giving even the slightest thought to personal interest and to life or death." ${ }^{14}$ To be a prisoner-of-war was shameful: a good Japanese serviceman would commit suicide rather than surrender. ${ }^{15}$ Through propaganda and ideology the state created a specific account of the soldier experience, an "official knowledge" of who and what a Japanese serviceman was. Soldiers were ostensibly the men who most directly fulfilled the Japanese mission to liberate Asian peoples, divest the West of its colonies, and bring order and stability to the East. They would do everything to protect the Emperor and obey his sacred will, selflessly hurdling themselves at the enemy in sacrificial acts of gyokusai (suicide attack) and special-attack flights. A soldier's death was not portrayed as tragic, but heroic: soldiers died fighting for the glory of the nation. This government account of the serviceman experience was certainly widespread, reaching the ears of each civilian: with hundreds of thousands conscripted into the armed forces each year of the war, every Japanese must have had a family member fighting and dying for the nation or could have expected that the military would imminently draft a loved one. In parades, parties, and processions, Japanese communities patriotically sent their men off to war. ${ }^{16}$

On the home front, neighborhood associations and community councils were most immediately tied to everyday life, constantly reminding the Japanese people of their duties to the war effort. These local administrative organizations provided the state with a "system of organizing and mobilizing individual citizens for the purpose of controlling them from above" by "conveying the will of the authorities to those below." ${ }^{17}$ Community councils and neighborhood associations first appeared in Japan in the 1930s to enhance the effectiveness of local administration. The councils included a few hundred households divided into neighborhood associations of ten to twenty families. ${ }^{18}$ But not until 1938 did the Home Ministry legally incorporate these organizations into the government's administrative apparatus. By September 1940 the state's "spiritual mobilization" leaders had established 79,028 community councils in cities and towns and 118,430 in the countryside. ${ }^{19}$ The councils primarily assisted police and fire officials, organized festivals, conducted inspections of people's homes, and collected taxes while the associations penetrated daily life even further by communicating with the councils, helping with air and fire defense, looking out for spies, encouraging savings deposits, enforcing governmental reforms, and distributing rations. ${ }^{20}$

\footnotetext{
${ }^{14}$ Field Service Code, Tokyo Gazette, Vol. IV, no. 9, 343-6.

${ }^{15}$ Saburo Ienaga, The Pacific War: 1931-1945: A Critical Perspective on Japan's Role in World War II, (New York: Pantheon Books, 1978), 49.

${ }^{16}$ John Dower, Embracing Defeat: Japan in the Wake of World War II, (New York: W.W. Norton \& Co., 1999), 59.

${ }^{17}$ Thomas R. H. Havens, Valley of Darkness: The Japanese People and World War Two, (New York: W.W. Norton \& Co., 1978), 41.

${ }^{18} \mathrm{Ibid}, 37$.

${ }^{19}$ Ibid, 39 .

${ }^{20}$ Ibid, 40, 77 .
} 
Aside from organizing its people into units intimately tied to the war effort, the Japanese government policed, legally restricted, and censored its citizens. In this way, the state ensured that others' "memory work" and "critical remembering" could not challenge its own reconstruction of the past. The most repressive laws severely limited freedom of expression and conscience. A 1941 amendment to The Peace Preservation Law allowed for the preventive detention of political activists and indefinite detention of political prisoners, enabling the state to permanently jail activists "unless they recanted their beliefs"; the 1941 National Defense Security Law made important government activities "state secrets" and provided harsh penalties for obtaining or divulging such information; the Provisional Law for Control of Speech, Publications, Assembly, and Association mandated that the government pre-approve activities of political organizations, political meetings, and publication of magazines and newspapers; and the 1943 Special Law on Wartime Crimes made it illegal to "disseminate information... which will harm public order for the purpose of interfering with national administration or public order." ${ }^{21}$ Moreover, there was widespread censorship and manipulation of news. Throughout the war, the state shut down thousands of newspapers and periodicals while the powerful Cabinet Information Bureau used "overt propaganda and manipulation" to control the media and ensure a perpetually positive portrayal of the war. ${ }^{22}$ Accordingly, the government also censored the Japanese literary world. It suppressed the works of writers encouraging values anathema to the state's ideology of complete unity and sacrifice and banned writers from "express[ing] even the smallest doubts about the war"-Donald Keene thus terms this period the "barren years." ${ }^{23}$ Overall, the Japanese state's barrage of propaganda, censorship, and daily control promoted a narrative suggesting that all Japanese tirelessly worked together to secure glory for their country.

Radical changes ensued during the Allied Occupation of Japan, and the Americans refigured the Japanese state's narrative of the war and soldier experience through their own "memory work." For the most part, the American occupiers silenced the war, avoiding discussion of its horrors and destruction. The Allies wanted to smoothly transition the Japanese out of their total war state and into a compliant passivity, enacting a program of "demilitarization and democratization." ${ }^{24}$ The new 1947 constitution was modeled on the American one, and ostensibly gave the Japanese self-rule through popular sovereignty. ${ }^{25}$ Divesting the Japanese people of complicity in the war became an essential occupying strategy, and the Allies styled the war as a misguided venture of Japanese leaders. ${ }^{26}$ This victor-victim figuration has lasted to the present, troubling historians like Lisa Yoneyama, T. Fujitani, Geoffrey White, Saburo Ienaga, John Dower, and Donald Keene who all address the presence of this dominant history of the war in their works. Indeed, Fujitani claims that the Japanese people still remember themselves as "a

\footnotetext{
${ }^{21}$ Ienaga, The Pacific War, 98-99.

${ }^{22}$ Havens, Valley of Darkness, 22; Ienaga, The Pacific War, 100.

${ }^{23}$ Havens, Valley of Darkness, 23; Donald Keene, "The Barren Years" in Monumenta Nipponica, Vol. 33, No. 1 (Spring, 1978), 68.

${ }^{24}$ John Dower, Japan in War and Peace, (New York: New Press, 1993), 165.

${ }^{25}$ Ienaga, The Pacific War, 241.

${ }^{26}$ Ibid, 249.
} 
singular and uniform collectivity that was victimized by the military elite... until they recovered their political agency in the wake of defeat." ${ }^{27}$ And importantly, it was the Americans who gave the Japanese the opportunity to recover this "political agency" - they were the liberators.

The power of the American censorship apparatus was crucial to formulating the postwar officialized history, a history supporting positive views of American liberators, a victimized characterization of the Japanese, and the democratic enlightenment of postwar Japan. Although the new Japanese government technically operated under the SCAP (Supreme Command for the Allied Powers) administration's September 1945 directive mandating freedom of speech so long as such expression adhered "to the truth" and did not disturb "public tranquility," censorship was widespread. ${ }^{28}$ Indeed, the Civil Censorship Detachment (CCD) was created within SCAP's Civil Information Section and monitored all media outlets and theatrical performances, employing over six thousand people throughout Japan at its peak. ${ }^{29}$ The Allied occupiers never actually acknowledged that censorship existed - they promoted a façade of democracy - and even though the CCD dissolved in 1949, some form of censorship continued throughout the occupation. ${ }^{30}$ Through the CCD, the Allies sought to prevent the Japanese from engaging in "memory work" and "critical remembering" that was subversive to the occupationist war history.

Unsurprisingly, wartime literature did not escape the Allied censors. The CCD reviewed and suppressed many literary figures' writings, and there is evidence that the victors even used writers to promote their postwar narrative. ${ }^{31}$ One such writer was Michio Takeyama who in 1946 penned the prize-winning Harp of Burma. ${ }^{32}$ Richard Minear reveals that Takeyama was a member of the pro-American, anti-communist Congress for Cultural Freedom, which was not only supported by important American intellectuals like Edward Seidensticker and Herbert Passin, but also drew financial support from the Central Intelligence Agency. ${ }^{33}$ With his anticommunist inclinations and American intellectual and CIA connections, it was unsurprising that Takeyama kindly characterized Westerners, primarily blamed Japanese leaders for the war, lamented over the victimized Japanese soldiers who died, and looked to the future of Japan in Harp of Burma - the protagonist Mizushima probingly asks, "Our country has waged a war, lost it, and is now suffering...can we not remain energetic and yet be less avaricious? Is that not essential-for the Japanese and for all humanity?" 34 The Allied victors used SCAP's censorship power to suppress voices contrasting with the official postwar narrative and to promote those that aligned with the dominant, pro-Western and victimization views. One undemocratic regime

\footnotetext{
${ }^{27}$ Fujitani, White, Yoneyama, Introduction to Perilous Memories, 7.

${ }^{28}$ Dower, Embracing Defeat, 407.

${ }^{29}$ Ibid, 407.

${ }^{30}$ Ibid, 408.

${ }^{31}$ Ibid, 408.

${ }^{32}$ Michio Takeyama, Harp of Burma, translated by Howard Hibbett, (North Clarendon, VT: Tuttle Classics, 1966).

${ }^{33}$ Richard H. Minear, The Scars of War: Tokyo During World War II: Writings of Takeyama Michio, (Lanham:

Rowman \& Littlefield, 2007), 19.

34 Takeyama, Harp of Burma, 130.
} 
to the next limited Japanese writing to certain topics and forced authors to be uncritical—at least on the surface - of the nation's new leaders.

Whether or not they wrote during the occupation period, all of the writers discussed here confronted the narratives that emerged within Japan during and after the war. As mentioned, this paper will focus on the soldier experiences detailed in Haruo Umezaki's 1946 "Sakurajima," Shohei Ooka's 1948 Taken Captive: A Japanese POW's Story and 1951 Fires on the Plain, Hiroshi Noma's 1952 Zone of Emptiness, Akira Yoshimura's 1967 Typhoon of Steel, and Hikaru Okuizumi's 1993 The Stones Cry Out. These stories, memoirs, and novels served as attempts to "critically remember" the Pacific War, denaturalizing and dismembering the aforementioned officialized narratives. ${ }^{35}$ The authors complicated and personalized the soldier experience, bringing servicemen out of the depths of Field Service Code characterizations and back to reality and humanity. Some of them subtly and creatively opposed the American occupation regime and embedded important political messages for their audiences within their writing, while others perpetuated the narrative of victimization and liberation. Most important, these works suggest that a new dominant narrative of the soldier experience has emerged; it is one focused on the embattled self, the struggle to reconcile past experiences with the present.

Haruo Umezaki's "Sakurajima" was one of the postwar era's first fictional works that concentrated on the Japanese soldier experience. Umezaki was a member of what historians term the sengoha (Postwar Group), comprised of authors who wrote in the decade following Japan's surrender and were united by their common experiences in the war. ${ }^{36}$ The sengoha also included Shohei Ooka and Hiroshi Noma, who, along with Umezaki, fought in the war. It is not clear whether or not "Sakurajima" evaded the censors, but Umezaki's work would certainly not have been published if it directly challenged American occupationist ideology. ${ }^{37}$ Indeed, many elements of "Sakurajima" fit well into the Allied war narrative. The protagonist, Petty Officer Murakami, who is stationed on the small southern Japanese island of Sakurajima in the final months of the conflict, has a negative view of war in general and finds his own situation particularly hopeless. Enlisted soldiers disturb Murakami: they had an "uncanny look in the eyes... They had a maniacal gleam behind them. They were not the eyes of an ordinary person. They were the eyes of a degenerate. ${ }^{38}$ Moreover, Murakami cannot bear to punish his own men, "felt as if [he] were choking" when his superior Chief Petty Officer Kira (the epitome of the demented enlisted men) punished them for him, accepts Japan's "overwhelming defeat" prior to

\footnotetext{
${ }^{35}$ Fujitani, White, and Yoneyama, Introduction to Perilous Memories, 4.

${ }^{36}$ Irmela Hijiya-Kirschnereit, "Post-World War II Literature: The Intellectual Climate in Japan, 1945-1985" in Legacies and Ambiguities: Postwar Fiction and Culture in West Germany and Japan, edited by Ernestine Schlant and J. Thomas Rimer (Washington, D.C.: Johns Hopkins University Press, 1991), 109.

${ }^{37}$ Marlene J. Mayo, "Literary Reorientation in Occupied Japan: Incidents of Civil Censorship" in Legacies and Ambiguities: Postwar Fiction and Culture in West Germany and Japan, edited by Ernestine Schlant and J. Thomas Rimer (Washington, D.C.: Johns Hopkins University Press, 1991), n. 38, pg. 158; Erik Lofgren, "Democratizing Illnesses: Umezaki Haruo, Censorship, and Subversion" in Comparative Literature Vol. 51, No. 2 (Duke University Press, Spring 2000), 177.

${ }^{38}$ Haruo Umezaki, "Sakurajima" in The Catch and Other War Stories, translated by D.E. Mills (Tokyo: Kodansha International Ltd., 1981), 72.
} 
formal surrender, believes he lives in "an entirely different world from" people like Kira, and either constantly fears his imminent death or questions why he has to die "like an abandoned cat on this island." 39 Through Murakami, Umezaki used "memory work" to reconstruct the soldier experience and to question the righteousness of the Japanese state in waging war and forcing its citizens into such a destructive mental and physical climate. He implicitly advocated for peace and passivity, something very favorable to the occupiers.

It would be shortsighted to say that "Sakurajima" merely supported the Allied postwar narrative. Umezaki did engage in a "critical remembering" of the war which not only shattered the wartime narrative promoted by Japanese propaganda, but also had implications for contemporary Japan. There is an unmistakable individualism to Umezaki's work. He wrote "Sakurajima" through the first-person lens of Murakami, revealing the soldier's deepest and most intimate thoughts. Murakami's thought process and character are indeed of critical import. His unwillingness to punish his comrades, his doubts about the war's ostensibly just intentions, and his eventual disgust with dying a "beautiful" death subverted the notion that all Japanese soldiers believed in the military's propaganda and were united in one seamless fighting mass. ${ }^{40}$ Murakami was distinct because he thought for himself.

But he was not the only character to deviate from the state's imposed Japanese essence of duty, unity, and sacrifice. Lieutenant Tani, commander of an observation station near Bonotsu, questions the idea of dying a "fine death" which the state so avidly promoted. He reduces this prime duty of soldiers to "nothing but sentimentality." 41 The tragic one-eared prostitute who sleeps with Murakami exclaims to him her deep unhappiness in a moment of "tenderness" which affects him throughout the story. ${ }^{42}$ The lookout at Sakurajima sees inhumanity in the Chief and Petty Officers and other volunteers, lamenting over those in suicide units who went to their deaths "without even knowing why." ${ }^{43}$ Even the cruel Officer Kira, whose "whole life" had revolved around the Japanese military, fails in the end to commit suicide after learning of defeat, fails to do what the Field Service Code demanded of him. ${ }^{44}$ This individualism of the "Sakurajima" characters - their ability to think for themselves and resist, at least internally, the self-subjectifying power of the state's propagandistic and militaristic spirit-was important because it implicitly demonstrated that Umezaki supported the democratic principles of freedom of thought and expression. His characters had vitality because of their ability to act and think in ways antithetical to the propagated norm. In a postwar Japan democratic in name only, which censored its citizens and monitored the Japanese intellectual, literary, and entertainment realms, Umezaki told a story that continually questioned authority, indirectly asking his audience to resist efforts of control and oppression-he "critically remembered" the war in a way that subverted the Allies' own "memory work." Although "Sakurajima” straightforwardly criticized

\footnotetext{
${ }^{39}$ Ibid, 65, 81, 83, 84, 85, 101.

${ }^{40}$ Ibid, 108 .

${ }^{41}$ Ibid, 65 .

${ }^{42}$ Ibid, 67.

${ }^{43}$ Ibid, 78, 93.

${ }^{44} \mathrm{Ibid}, 79,117$.
} 
the war and the Japanese state, it also reflected upon Japan's postwar oppressions and subtly denounced a truly undemocratic "democratization" process.

The writer Shohei Ooka similarly wrote about soldier experiences in the immediate postwar years, publishing his two most celebrated works, the memoir Taken Captive and the novel Fires on the Plain, in 1948 and 1951 respectively; yet he went further than Umezaki in challenging the Allied occupationist narrative..$^{45}$ The CCD censorship apparatus unsurprisingly influenced Ooka's literature. He originally published Taken Captive in the anti-Marxist journal Bungakkai and had to delete specific passages detailing his treatment by Americans in the POW camp and change certain words, like "enemy" to "opponent." ${ }^{46}$ Ooka did indeed depict his American captors in generally kind and appreciative terms from the start of his detainment: "I already knew from the way I had been treated that I was in the hands of a civilized nation." ${ }^{47}$ His "memory work" also involved characterizing the Japanese state as the main perpetrator in the war, relieving his comrades of culpability in the atrocities they committed. At various points in the memoir, he wrote of how "the General Staff...had dragged our country into such a hopeless fight" and corrupted the minds of soldiers, who "must be considered pitiable victims." ${ }^{\text {" }}$ Thus, like Umezaki, Ooka's "critical remembering" helped dismantle false pretensions of universal soldier unity and loyalty and censured his leaders. Ooka proved that soldiers could be individuals, thinking and reasoning for themselves. Moreover, his benevolent characterization of Americans and decidedly Western outlook-Ooka was a student of French literature and almost all of his many literary and theoretical references come from Western thinkers-supported an occupation regime creating an official postwar history stressing the liberation of the Japanese people through Western democratic models. ${ }^{49}$

Yet Ooka's remembrances in Taken Captive provided a new perspective on the war and postwar periods. Ooka's "critical remembering" was, in fact, deeply subversive and strongly critical of the Allied Occupation. The key to this analysis comes in the epigraph, a quote from Defoe's Robinson Crusoe: "[It is] reasonable to represent one kind of imprisonment by another." ${ }^{0}$ Ooka wrote in a post-occupation edition of Taken Captive that the "meaning [he] wanted to give was to satirize Japan under the Occupation through the depiction of a POW camp." ${ }^{11}$ On one hand, his "critical remembering" recuperated the memory of life in the camps. On the other, his "memory work" secretly embedded into his memoir a political message to the Japanese peopleprisoner-of-war became analogous with prisoner-of-occupation.

\footnotetext{
${ }^{45}$ Translator Wayne Lammers noted that Taken Captive was published in nine different journals between February 1948 and January 1951.

${ }^{46}$ Mayo, "Civil Censorship in Occupied Japan," 146.

${ }^{47}$ Shohei Ooka, Taken Captive: A Japanese POW's Story, translated and edited by Wayne P. Lammers, (New York: John Wiley \& Sons, Inc., 1996), 35, 37, 129, 167.

${ }^{48}$ Ibid, 5, 6, 42, 65, 66, 144.

${ }^{49}$ In Taken Captive see v, 18, 24, 261-3 for references to Defoe, Stendhal, Dostoyevsky, Gide, Wilde, and Aristotle. In Fires on the Plain see 72, 92, 115, 178 for references to Defoe, Bergson, Dostoyevsky, and French history.

${ }^{50}$ Ibid, v.

${ }^{51}$ Lofgren, "Democratizing Illnesses," 164.
} 
Indeed, Ooka's POW camp had its own political organization that ironically reflected conditions in postwar Japan. Americans allowed the imprisoned Japanese to function basically for themselves within the camps, just as the Americans gave the Japanese self-government through democracy. But there were constant reminders of American power over the prisoners, a power that haunted Ooka:

We encountered nothing particularly new on the battlefield, but we did in the POW camp. Most notably, there was the fence that encircled us. Though we brought nothing back from the battlefield, something has unquestionably stayed with us from our lives as POWs-something that occasionally whispers in my ear, "You're still a prisoner, you know." 52

Even though a political hierarchy developed among the prisoners, with each man having a different "station," the Americans ultimately controlled the camp just as they dominated Japanese politics and policy between 1945 and 1952.53 For Ooka this domination was a problem-"These men ruled and watched, and the prisoners lived. But can prisoners really live? Are they truly buman?" 54 The occupiers stripped the Japanese people of their agency, forcing them into subservience to and partnership with an overseeing American military regime dominated by General MacArthur and his SCAP bureaucracy. Ooka's "memory work" thus served as an allegorical critique of present conditions in Japan, a cleverly subversive condemnation of American rule. But Ooka went a step further. He censured his own people for their passivity and acceptance of such an undemocratic regime. His disappointment with his fellow men who so easily accepted POW life was palpable: "Men who once blindly laid down their lives without reflecting on what it truly meant allowed themselves to become intoxicated with the sweetness of POW life, utterly oblivious to what the implications might be. ${ }^{55}$ His "critical remembering" and "memory work" were unsettling to both the wartime and postwar officialized histories. Without explicitly saying, Ooka urged the Japanese to reconsider the effects of their complacence during the war, and to become actively engaged in a postwar climate that was depriving them of basic democratic rights and creating a government without citizen input.

Ooka's 1951 novel Fires on the Plain similarly followed a soldier's experience on the island of Leyte in the Philippines. Like other sengoha writers, Ooka critiqued army superiors. In fact, the book opens with a squad leader hitting the protagonist, Private Tamura, in the face for being sent back to his unit from the hospital. ${ }^{56}$ Tamura's squad then proceeds to abandon him due to his consumption, leaving him with "six small potatoes" on which to survive. Tamura bitingly remarks: "to this extent and no further was my country prepared to guarantee my survival: this

\footnotetext{
${ }^{52}$ Ooka, Taken Captive, 149.

${ }^{53}$ Ibid, $150-1$.

${ }^{54}$ Ibid, 131.

${ }^{55} \mathrm{Ibid}, 126,130,215$.

${ }^{56}$ Shohei Ooka, Fires on the Plain, translated by Ivan Morris, (Boston: Tuttle Publishing, 2001), 3.
} 
country of mine to which I was offering my life." ${ }^{57} \mathrm{He}$ proves to be of no more use to his comrades, and they force him to join those other sick and wounded whom "had all been thrown out of their companies and left to their fates." 58 These men's abandonment signified how little the army really operated as a unified whole, thus diverging from the state's account of the soldier experience. The abandonment highlighted Tamura's struggles as an independent person, distinct from his military organization. Moreover, much of the emotive power of Fires on the Plain came from Ooka's vivid descriptions of life in a war zone. The other sengoha writers also engaged in such "memory work," publicizing battle conditions that had never reached the people due to Japan's heavily censored media outlets. The most important of Ooka's contributions were his passages on cannibalism-Tamura's horror at a dying man lifting his arm saying, "When I'm dead, you may eat this," his eating of purported "monkey meat" (which was actually the flesh of Japanese soldiers who had died wandering Leyte's forests), his realization of this fact, and his finding of the massive pile of "gastronomically useless" parts of the body: the hands and feet. ${ }^{59}$

Tamura's accidental cannibalism, along with his abandonment, murder of a woman, and general struggles surviving in the Philippines drove him to madness, and ripped apart his identity. This split identity was the most important aspect of Fires on the Plain; for as Ooka revealed in the final chapters, the entire book had been Tamura's remembrances from a mental hospital. He attempts to remember the war in order to connect his present self to his past and cure his insanity:

The method (if indeed one exists) of transforming into necessity the chance that dominates my present life probably lies in finding the link between this life and that past in which chance was forced on me by authority. It is for this reason that I am writing these notes. ${ }^{60}$

Indeed, this split self permeates the story. Highly rationalized moments of analysis intertwine with Christian revelations and instances of utter horror. ${ }^{61}$ Ooka showed how immensely damaging war could be physically as well as psychologically. He reconstructed the soldier as fragile and human, an individual trying to find meaning out of this world. Tamura's story also had "present purposes," serving as a lesson for the Japanese people during Occupation:

The reports in the newspapers...seem to be trying to force me into the thing that I want least of all, namely, another war. Wars may be advantageous to the small group of gentlemen who direct them, and I therefore leave these people aside; what baffles me is all the other men and women who now once again seem so anxious to be deluded by

\footnotetext{
${ }^{57} \mathrm{Ibid}, 7$.

${ }_{58}^{58}$ Ibid, 4.

${ }^{59} \mathrm{Ibid}$, 186, 198, 216, 217.

${ }^{60} \mathrm{Ibid}, 234$.

${ }^{61}$ Ibid, for moments of particular rationality see 91-93, 178, for Christianity see 107-112, 191, 194, 205, for horror see 169-170, 186-187.
} 
these gentlemen. Perhaps they will not understand until they have gone through experiences like those I had in the Philippine mountains; then their eyes will be opened. ${ }^{62}$

As the Americans began to remilitarize Japan for the approaching Korean War, Ooka presented the Japanese with this politically charged account of the soldier experience. The Pacific War had fractured Tamura's identity, stripped him of his sanity, and left him in a mental hospital. Fires on the Plain thus sent a distinct anti-war message to the Japanese, begging them to look at what their own government had forced them through and to decide if they really wanted to enter yet another war.

Hiroshi Noma's 1952 Zone of Emptiness differed from Ooka's and Umezaki's works in a critically important way. Noma reflected upon abuses between Japanese, rather than commenting negatively on American-Japanese interactions. Indeed, the entire novel centered on the abuse of Private First Class Kitani, who was finally released from a two-and-a-half-year prison sentence for stealing his lieutenant's wallet, a false charge. Kitani continues to fall into the system of subjection and oppression that was the Japanese Imperial Army. Donald Keene elucidated that Noma created Kitani as a character meant to "depict the Japanese people as a whole during the war."63 Noma "critically remembered" the war through his protagonist. A single individual condemns the entire military apparatus. In fact, Kitani's character was so remarkable due to this independence and individualism - his position as an outcast, a man on the periphery, allows him to recognize injustice. When the army ordered Kitani's certainly fatal deployment in the South Seas, a sergeant tells him that his "departure for the front will be the beginning of a new life for you. It is an opportunity to become a real soldier again." ${ }^{64}$ The words are almost comical to Kitani, and "he regarded the man as his enemy." ${ }^{65}$ And at the prospect of embarkation, when soldiers speak of "[blazing] a path of honor for those who'll soon be with us," Kitani reviles them as fools, crying out: "What a pack of idiots!" ${ }^{66}$ His ability to act as an individual and separate himself from the militaristic mindset enables him to see the truth. The novel is also riddled with the profligate corruption of army superiors, especially that of Lieutenant Hiyashi, the man whose wallet Kitani supposedly stole. ${ }^{67}$ Noma's remembering thus coalesced with that of the other sengoha writers in his attempts to configure ordinary soldiers as victims to the treachery of superiors.

Noma's "memory work" and "critical remembering" also had "present purposes." As he said in his significant "Author's Preface," “...foreigners must be informed that the Japanese people did not identify their destiny with that of militarism. I hope that my novel will provide

\footnotetext{
${ }^{62}$ Ibid, 232.

${ }^{63}$ Donald Keene, Dawn to the West: Japanese Literature of the Modern Era, (New York: Holt, Reinhart and Winston), 980.

${ }^{64}$ Hiroshi Noma, Zone of Emptiness, translated by Bernard Frechtman, (Cleveland: The World Publishing Company, 1956), 279.

${ }^{65}$ Ibid, 280.

${ }^{66}$ Ibid, 281.

${ }^{67} \mathrm{Ibid}$, 64, 71, 74, 82, 93, 111, 122, 124, 143, 162, 169.
} 
the reader with a true picture of what my country was like when it was under the yoke of this dominating force." ${ }^{68}$ His "memory work" aimed to revalidate Japan to the world. Not all Japanese had that corrupting "military spirit"; they really could "choose peace." ${ }^{69}$ Noma's focus on the tragedies of militarism's inequality served to promote egalitarianism and a more democratic Japanese state. But, like Ooka, he also warned of "the rearmament of Japan and the rebirth of the militaristic spirit." In his belief that "the Japanese people will reject these solutions," he implicitly advocated that the Japanese reject the American military's will, and chart their own course for the future. ${ }^{70}$

Akira Yoshimura published his novel Typhoon of Steel in 1967. Although Yoshimura did not significantly challenge the officialized history of victim-hood-which was significant in itself-he does depart from most postwar writers by focusing on an Okinawan's war experience. It told the story of the fourteen-year old Okinawan schoolboy Shin'ichi Higa, who is conscripted into the army along with his classmates to serve in the ensuing Battle of Okinawa. Writing fifteen years after the occupation period, Yoshimura and the Japanese people were well aware of the horrors of the Pacific War, which writers like Noma and Ooka started to recover in their own literary remembrances. Much of the force of Typhoon of Steel came in its recapitulation of this horrific imagery —Shin'ichi being "pinned beneath a pile of [dead] bodies," drinking his own urine from thirst, getting water from a river where "there were so many bodies piled up on top of each other that he struggled to find gaps in which to place his feet," and encountering a plethora of maggots in nearly all of his daily activities. ${ }^{71}$ Yoshimura's "memory work" also contributed to the officialized history by perpetuating the Japanese-as-victim rhetoric. Indeed, Shin'ichi is a young teenager, and accepts the Japanese propaganda as truth without question. But his ardent support of the war effort and constant desire to sacrifice himself to achieve glory and "be enshrined with the war heroes at Yasukuni Shrine in Tokyo," comes off as his youth at play-his innocent and tragic entrapment within the Japanese state's propagandistic ideology. ${ }^{72}$ In fact, Shin'ichi's loyalty to the state appears more connected to typical childhood desires to gain selfrecognition and to participate in something with friends than a real dedication to Japan and its war. Although he is one of the senior boys at his school, Shin'ichi was small- "There were many boys among the junior pupils whose physical maturity put Shin'ichi to shame"-and he felt that "the tension surrounding the imminent American invasion served to highlight his higher position in the hierarchy." ${ }^{73}$ Moreover, both of Shin'ichi's brothers already died in the war and he feels a duty to contribute to the same cause- "We are prepared to fight, and die, to protect the lives of women and little children. That's what my brothers did, and that's what I will do." ${ }^{74} \mathrm{He}$

\footnotetext{
${ }^{68}$ Ibid, v.

${ }^{69}$ Ibid, v.

${ }^{70}$ Ibid, v.

${ }^{71}$ Akira Yoshimura, Typhoon of Steel: An Okinawan Schoolboy's Quest for Martyrdom in the Battle of Okinawa, translated by Mark Ealey, (Portland, Maine: Merwin Asia, 2009), 162, 176, 189.

${ }^{72} \mathrm{Ibid}, 22$.

${ }^{73}$ Ibid, 3.

${ }^{74} \mathrm{Ibid}, 69$.
} 
fails to understand his own objectification, and the novel is peppered with instances of Shin'ichi seeing how he was simply another body for the military to use, but not quite accepting his marginality ${ }^{75} \mathrm{He}$ cannot separate himself from the idealized soldier image, failing to think as an individual and realize the truth of his own hopeless situation. He is victim not only to childhood pretensions, but to his government as well.

Yoshimura may not have done much to dispel the "official history" of victim-hood that emerged in the postwar period, but his "memory work" was still significant due to the novel's focus on an Okinawan's experience. After 1945, Americans occupied Okinawa and proceeded to establish military bases throughout the island. The formal occupation lasted for twenty-seven years, far longer than it did on the home islands. ${ }^{76}$ Okinawa was, and remains, the heart of American military presence in the Pacific-it was where the United States military promoted itself as a conquering force and as the "new defender of freedom and democracy for Okinawa and Japan, and indeed, for the entire world." ${ }^{\prime 7}$ However, Americans continually oppressed the Okinawans, denying them "their basic human rights and [treating] them with contempt." 78 Masaie Ishihara writes of how there were little organized efforts to record survivors' accounts of the Battle of Okinawa until 1970, and thus Yoshimura's own rendering of the battle may be seen as an early attempt at recuperating these suppressed memories. ${ }^{79}$ His "memory work" can be interpreted as a commentary on the continued victimization of the Okinawan people, and as a slight against the Japanese government for failing to protect Okinawan rights. Despite Japan's democratic constitution, these citizens did not benefit from their country's democracy-they remained an oppressed minority. Indeed, Shin'ichi's faith in Japan must be read with irony-"I'm Japanese, thought Shin'ichi. This is a heaven-sent opportunity for the people of Okinawa to demonstrate their strength to the rest of Japan." ${ }^{80}$ In 1967, readers would have been forced to realize the tragic fatuity in such a statement, which raised those Yoneyamian "self-critically unsettling" questions: were the marginalized Okinawans ever truly considered Japanese? Were those poverty-stricken people still suffering under the yoke of American militarism really part of the national consciousness? These implicit questions within Yoshimura's work made Typhoon of Steel more than just a recapitulation of recently recovered memories. He questioned the justice in the plight of Okinawa both in the nation's past and present and asked his readers to do the same, prompting them to reconsider Japan's policy toward Okinawans.

Hikaru Okuizumi, who wrote The Stones Cry Out in 1993-a more recent postOccupation novel-significantly asked his readers to engage in a process of reconciliation regarding the war. The novel traces Tsuyoshi Manase's journey of revelation in the decades following the war. Manase, who served in Leyte, carries a powerful memory of his interaction with a dying man in a cave. This dying soldier's speech about stones seared into Manase's mind

\footnotetext{
${ }^{75}$ Ibid, 45, 66, 126, 156.

${ }^{76}$ Masaie Ishihara, "Memories of War and Okinawa," translated by Douglass Dreistadt, in Perilous Memories, 95.

${ }^{77}$ Fujitani, White, and Yoneyama, Introduction to Perilous Memories, 12.

${ }^{78}$ Ishihara Masaie, "Memories of War and Okinawa," Perilous, 103.

${ }^{79}$ Ibid, 97.

${ }^{80}$ Yoshimura, Typhoon of Steel, 22.
} 
the idea that "even the plainest, most ordinary pebble has the history of the universe written on it." ${ }^{" 11}$ The cave experience launches Manase into an obsession with stone collecting after the war, a hobby which eventually leads to his young son's murder in a cave, the collapse of his marriage, the neglect of his second son, and finally his self-discovery. What was significant about The Stones Cry Out was not the mere plot, but rather how Okuizumi's "critical remembering" matched or diverged from those writing before him. Born in 1956, Okuizumi is the only author analyzed in this paper who experienced neither the war nor Allied Occupation. He thus could not have drawn from any personal Pacific War experiences in order to contextualize Manase's. In this respect, Okuizumi's "memory work" and "critical remembering" did not add anything particularly new to memories of war conditions. Haunting the cave memory are the cruelty of the Japanese captain - a man who ordered the killing of all sick soldiers and who would manically polish the sword he used to slit their throats—and the maggots infesting the dying soldier's eyes who spoke of the stones- "maggots squirm[ing] in the eyes of a breathing, talking human being." ${ }^{82}$ Superiors' brutality and gruesome living conditions matched with an established soldier narrative recuperated during the postwar years. Manase's embattled, damaged self searching to reconcile his war experience with his postwar life built upon an emerging "official knowledge" of the Japanese soldier, as detailed further below. In these respects Okuizumi's memory work did not create "gaps and slippages" in the postwar historical framework, but drew upon tropes already used in others' "memory work" to historicize the war. ${ }^{83}$

The Stones Cry Out was not, however, a simple recapitulation of Umezaki, Ooka, and Noma, and Yoshimura's refiguring of the war. Manase's story was one of expiation, and through it Okuizumi urged his readers to engage in a similar process of remembrance and reconciliation - to unearth those deep memories and come to terms with the truth of their pasts. If Okuizumi did not bring to light an unsettling account of the war for his audience, then Manase certainly does for himself. In fact, he finally discovers that he was the one who killed that dying soldier who lectured him about the stones. Following his captain's orders, Manase murdered a man whose only wish was to see the sun rise one last time. ${ }^{84}$ Stones, whose geological properties unveiled the "history of the universe," also held the key to unveiling Manase's full identity. He needs to uncover his deeply suppressed memory in order to repent for his sin and finally accept the series of tragedies in his life. In a moment of catharsis laden with Christian imagery, Manase refigures his own past by reliving the cave memory and saving the dying soldier's life. As recompense he receives a stone transformed "into a radiant crystal," as if his soul had been saved. ${ }^{85}$ Through Manase's example, Okuizumi indirectly asked his audience to "critically remember" their pasts in order to fill those gaps and voids in their own life histories and achieve a spiritual fulfillment. Although this message was universal, it especially applied to

\footnotetext{
${ }^{81}$ Hikaru Okuizumi, The Stones Cry Out, translated by James Westerhoven, (New York: Harcourt Brace \& Co.), 53.

${ }^{82}$ Ibid, 5, 24, 84, 87, 134.

${ }^{83}$ Yoneyama, Hiroshima Traces, 33.

${ }^{84}$ Okuizumi, The Stones Cry Out, 87.

${ }^{85} \mathrm{Ibid}, 138$.
} 
soldiers who, as Manase indicated, had these types of violent and horrific deep memories that almost no other people in society carried. Unsettle your own pasts and unlock your suppressed memories, Okuizumi asked, and you will find salvation.

As distinct pieces, the books and stories analyzed above confirm, deny, subvert, or augment dominant narratives of the war and postwar periods - they contain a disparate array of remembrances and reconstructions, criticisms and affirmations, "gaps and slippages." But overarching conclusions arise when considering these works together. First, the writers "memory work" and "critical remembering" completely subverted and overturned the wartime "official history" propagated by the Japanese state. The Japanese people and soldiers were to be completely focused on the war effort, imbued with the unifying and loving spirit of kokutai. Unity, sacrifice, and loyalty were most important to soldiers: fulfilling Japan's mission of "liberating" other Asian peoples and creating the Greater East Asian Co-Prosperity Sphere depended on military accomplishments. But many authors fighting in the war remembered or depicted the action differently — certainly none of their characters contained anything resembling the spirit of kokutai that the government wished them to possess. The characters in their novels constantly complained of their superiors' brutality, and many saw faults with the war on the whole. Chief Petty Officer Kira in "Sakurajima," the squad leader slapping Tamura in Fires on the Plain, Lieutenant Hayashi in Zone of Emptiness, and the sadistic corporal in The Stones Cry Out epitomized the fallacies of the military's ideology through their utter disrespect for the men they led. Zone of Emptiness rarely even mentioned the American enemy-it focused entirely on the subjection and oppression within the Japanese military apparatus. Even though Yoshimura described Shin'ichi's positive views of Japan in Typhoon of Steel, the boy's overwhelming marginalization within the army commented on how little the military cared for its men. Moreover, the soldiers featured in these writings were shown to be (for the most part) independent thinkers-they were not the mindless servicemen who felt a part of the "one hundred million hearts beating as one. ${ }^{" 86}$

This independence leads to the second major conclusion: the authors' "memory work" colored soldiers as individualists. Each work represented an internalized narrative of the war, portraying the conflict through the eyes of individuals without the pretension of creating a universal soldier history. Both Umezaki and Ooka utilized the first-person viewpoint, and every other author closely followed one individual. The stories of Petty Officer Murakami, POW Ooka, Private Tamura, Private Kitani, and stone collector Manase all promoted independence of thought and action, and the experiences of schoolboy Shin'ichi Higa revealed the tragic faults of thoughtlessly following mass propaganda. These first two conclusions suggest that the authors gave soldiers agency as individual thinkers, showing them as distinct from their military organization. Many Japanese treated returning soldiers "as pariahs in their native land" due to their ultimate loss in the war and the publicity of the atrocities committed by the army across Asia and against Allied prisoners. "Memory work" that distinguished servicemen from the

${ }^{86}$ Dower, Embracing Defeat, 59.

${ }^{87}$ Ibid, 60. 
military and characterized them in a more thoughtful, humanizing light promoted a revalidation of their characters.

Third, the authors often did not subvert the officialized Occupation narrative that stressed democratic liberation of the Japanese people, promoted a victimized Japanese character, and blamed the state's leaders for the war-in these cases, they did not engage in "critical remembering." The best example of this coalescence with the occupationist history was Noma's Zone of Emptiness, which, in addition to condemning military leadership, specifically reached out to "westerners" so that they were "informed that the Japanese people did not identify their destiny with that of militarism." 88 As illustrated in the above analyses, almost all of the soldiers in these stories see themselves and their comrades as victims of the state, forced unnecessarily into war. The only novel in which the soldier did not self-identify as a victim was Typhoon of Steel, but Yoshimura made the young Shin'ichi's victimization tangibly evident. He continuously highlighted the boy's failure to see the faults of a misguided war rhetoric. At times, authors had no choice but to support the Allied postwar liberation trope. In order to publish their works, the sengoha writers needed to adhere to the CCD's censorship policies that prohibited mention of a plethora of topics - anything from "Criticism of the Occupation Forces" to "Criticism of SCAP" to the extremely vague "Untrue Statements." 99

Fourth, these authors did in fact write with "present purposes" in the postwar period despite their occasional support of the official history. They engaged in a "critical remembering" that dismembered officialized memories and historical constructions of the war. In fact, the "critical remembering" and "memory work" analytic approaches revealed that the authors were particularly concerned with democracy in Japan. The expressive, yet oppressed "Sakurajima" characters allowed Umezaki to subtly critique the paradoxically imposed democratic reforms. Ooka most powerfully condemned the Allied Occupation within his novelistic memoir Taken Captive. Moreover, he represented the oppression of Japan under MacArthur's SCAP administration metaphorically through his experiences in a prisoner-of-war camp. Noma's concentration on the inequalities of army life implicitly promoted equality, peace, and freedom of choice among the Japanese people. Finally, Typhoon of Steel brought the plight of the often forgotten Okinawans into focus. Written in 1967 while Americans still had formal control over Okinawa, the book criticized the Japanese people for neglecting to protect the rights of their continuously marginalized brethren. It also highlighted the irony in the American military's claim that its possession of Okinawa facilitated the spread of peace, freedom, and democracy. In order to secure Okinawa, the Americans indeed had to fight one of the most violent, deadly, and horrific battles in history, a battle that came at the end of the war when Japan's defeat was already imminent.

Finally, and perhaps most important, the writers' "memory work" and "critical remembering" contributed to the creation of a new dominant history of the soldier experience. The soldiers in the works were engaged in a struggle with the self, with reconciling themselves to

\footnotetext{
${ }^{88}$ Noma, Zone of Emptiness, v.

${ }^{89}$ Dower, Embracing Defeat, 411.
} 
their present situations. The sengoba writers built the foundation of this memory which Yoshimura and especially Okuizumi used in their own novels. Ooka's Tamura best exemplified the embattled self: he specifically writes in order to mend his identity, to find some coherence within himself after the war ripped him apart. The split self appeared in "Sakurajima" and Zone of Emptiness as well. Murakami refuses to accept his imminent death and chooses instead to fantasize over a "beautiful" one. ${ }^{90}$ The constant threat of death created a tortured self, leading Murakami to one last morbid hope, that at least his death would be beautiful. Only when he sees the death of his friend the lookout did Murakami realize his own flawed logic- "How could destruction possibly be beautiful?" 91 Kitani's fractured identity was never repaired. He cannot escape the marginalization resulting from his imprisonment as the wallet thief. Noma asked his audience to recover Kitani's identity, to revalidate the oppressed soldier by accepting the Japanese people as peaceful. Yoshimura projected the embattled self onto the young Shin'ichi, who for fleeting moments desires to resist his sacrificial duty to the Japanese Army: his mother's sadness about his conscription troubles him; he begins to see suicide attacks, in which he longed to participate, as "strange" in their "being ordered in such a matter-of-fact way"; and when he had the opportunity to end his life and jump off a cliff rather than being captured, Shin'ichi is "gripped by fear" and "started running." Even if Shin'ichi did not comprehend his own hesitations, these moments illustrated his subconscious recognition that there was something wrong about the ideology he was following, something inside himself resisting. Last, Manase in The Stones Cry Out is clearly a torn self, struggling for years after the war to uncover his deep memories and find a way to reconcile his past and present. Interestingly, Okuizumi wrote in 1993. It thus appeared that his own configuration of the soldier was a projection of what he had seen previously in works like Fires on the Plain, Zone of Emptiness, and Typhoon of Steel. The conflicted self reappeared again and again in all of these works. If these memories of the soldier experience have evolved into a new dominant form of remembering, then they fail to be "selfcritically unsettling." They become accepted as a norm, taken for granted-they fall into the Yoneyamian memory trap.

Postwar Japanese writers detailing soldier experiences remembered the war in a way that responded to two powerful narratives. Haruo Umezaki, Shohei Ooka, Hiroshi Noma, Akira Yoshimura, and Hikaru Okuizumi dismantled the wartime narrative that created the idea of the sacrificial, loyal soldier mindlessly dedicated to the state. Instead, their "memory work" reconfigured the soldier identity. The soldier was an individual who could think for himself, and did not necessarily support the war effort. Although many of the postwar writers gave credence to the officialized rhetoric of a victimized Japanese people, they also wrote with "present purposes" on matters with "urgent political stakes." Indeed, these writers criticized their occupiers and pressed for greater democratic reforms. They highlighted the irony in occupationist narratives, seeking to fill those "voids" in knowledge and truth that the officialized

\footnotetext{
${ }^{90}$ Umezaki, "Sakurajima," 85, 102.

${ }^{91}$ Ibid, 108.

${ }^{92}$ Yoshimura, Typhoon of Steel, 69, 126, 222.
} 
history of liberation sought to cover. Yet, as with what happens with memory production so often, the postwar writers' remembrances began to form a new "official history" of the soldier experience: that of the split self, battling to reconcile past horrors with the present. However, as Lisa Yoneyama or T. Fujitani might say, dominant memories can always be complicated, overturned, and reworked. We just have to do that "critical remembering" and unsettle the past.

\section{Works Cited}

Dower, John. Embracing Defeat: Japan in the Wake of World War II. New York: W.W. Norton \& Company, 1999.

Dower, John. Japan in War and Peace. New York: New Press, 1993.

Field Service Code. Tokyo Gazette, Vol. IV, no. 9, 343-6. 1941.

Fujitani, T. and Geoffrey White, Lisa Yoneyama. Introduction to Perilous Memories: The AsiaPacific War(s). Durham: Duke University Press, 2001.

Gauntlett, John Owenn, ed. Hall, Robert King, trans. Kokutai No Hongi: Cardinal Principles of the National Entity of Japan. Cambridge: Harvard University Press, 1949.

Havens, Thomas R. H. Valley of Darkness: The Japanese People and World War Two. New York: W.W. Norton \& Company, 1978.

Hijiya-Kirschnereit, Irmela. "Post-World War II Literature: The Intellectual Climate in Japan, 1945-1985." In Legacies and Ambiguities: Postwar Fiction and Culture in West Germany and Japan. Edited by Ernestine Schlant and J. Thomas Rimer. Washington, D.C.: Johns Hopkins University Press, 1991.

Ienaga, Saburo. The Pacific War: 1931-1945: A Critical Perspective on Japan's Role in World War II. Translated by Frank Baldwin. New York: Pantheon Books, 1978.

Keene, Donald. “The Barren Years: Japanese War Literature.” In Monumenta Nipponica, Vol. 33, No. 1 (Spring, 1978), 67-112.

Keene, Donald. Dawn to the West: Japanese Literature of the Modern Era. New York: Holt, Rinehart and Winston, 1984.

Lofgren, Erik. "Democratizing Illnesses: Umezaki Haruo, Censorship, and Subversion." In Comparative Literature, Vol. 51, No. 2. Durham: Duke University Press (Spring 2000), 157178.

Ishihara, Masaie. "Memories of War and Okinawa." Translated by Douglass Dreistadt. In Perilous Memories: The Asia-Pacific War(s). Edited by T. Fujitani, Geoffrey M. White, and Lisa Yoneyama. Durham: Duke University Press, 2001.

Mayo, Marlene J. "Literary Reorientation in Occupied Japan: Incidents of Civil Censorship." In Legacies and Ambiguities: Postwar Fiction and Culture in West Germany and Japan. Edited by Ernestine Schlant and J. Thomas Rimer. Washington, D.C.: Johns Hopkins University Press, 1991.

Minear, Richard H. The Scars of War: Tokyo During World War II: Writings of Takeyama Michio. Lanham: Rowman \& Littlefield, 2007. 
Noma, Hiroshi. Zone of Emptiness. Translated by Bernard Frechtman. Cleveland: The World Publishing Company, 1956.

Okuizumi, Hikaru. The Stones Cry Out. Translated by James Westerhoven. New York: Harcourt Brace \& Company, 1998.

Ooka, Shohei. Fires on the Plain. Translated by Ivan Morris. Boston: Tuttle Publishing, 2001.

Ooka, Shohei. Taken Captive: A Japanese POW's Story. Translated and edited by Wayne P. Lammers. New York: John Wiley \& Sons, Inc., 1996.

Takeyama, Michio. Harp of Burma. Translated by Howard Hibbett. Tokyo: Tuttle Classics, 1966.

The Way of Subjects. Appendix A in Tolischus, Otto D. Tokyo Record. New York: Reynal \& Hitchcock, 1943.

Umezaki, Haruo. "Sakurajima." Translated by D. E. Mills. In The Catch and Other War Stories. Edited by Shoichi Saeki. Tokyo: Kodansha International LTD, 1981.

Yoneyama, Lisa. Hiroshima Traces: Time, Space, and the Dialectics of Memory. Berkeley: University of California Press, 1999.

Yoshimura, Akira. Typhoon of Steel: An Okinawan Schoolboy's Quest for Martyrdom in the Battle of Okinawa. Translated by Mark Ealey. Portland, Maine: Merwin Asia, 2009. 